\title{
Weaver-Birds' crop-Raiding Behavior in Buea municipality, Southwest Region, Cameroon
}

\author{
Melle Ekane Maurice,* Kato Samuel Namuene, Ewane Divine, Mbole Veronique, Agborta Sylvie Oyong \\ Department of Forestry and Wildlife, University of Buea, Cameroon
}

\begin{abstract}
The entire surface of the earth is visited by the birds in view of their aerial flights and variable habitats in search of suitable breeding and feeding grounds. Flight, intelligence, adaptability and sight are some of the attributes that add to the diversity in the life of birds, consequently there is complexity in their overall behavioral pattern. The key objective of this study was to assess the weaver-bird crop-raiding activity in Buea municipality on different environmental parameters. The study was undertaken for three months, six days in a week, from 7:00am to 6:00pm. Scan observations were made on birds' activity on a five-minute interval period across the entire study area. Simultaneously, data was collected on the environmental conditions. The study recorded a significant association between weaver-bird activity on crop-land, $\mathrm{X}^{2}=11.653 \mathrm{df}=14, \mathrm{P}<0.005$ and $\mathrm{X}^{2}=3.441 \mathrm{df}=4$, $\mathrm{P}<0.05$ respectively. There was weaver-bird activity frequency of $51.63 \%, 45.35 \%$, and $3.02 \%$ for Ploceus luteolus, Ploceus cuculatus, and Ploceus melanocephalus respectively. Moreover, a week association between bird activity and weather, $\mathrm{X}^{2}=3.125 \mathrm{df}=3, \mathrm{P}<0.05$ was recorded. The sunny and cloudy weather conditions recorded $53.26 \%$, and $42.09 \%$ respectively, while the windy and rainy weather conditions were significantly low (3.26\%). An association was recored between atmospheric conditions and weaver-birds' activity on crops, $\mathrm{X}^{2}=23.249 \mathrm{df}=21, \mathrm{P}<0.05$. In addition, the most destroyed farms were Elaeis guineensis (32.33\%), Saccharum officinarum (19.77\%), Zea mays (17.44\%), and Mangifera indica (15.58\%) respectively, and the scale of destruction was very prominent on the foliage used by the birds for nest-building. Maize crops and oil-palms were among the crop species most subjected to destruction by birds. These crops were observed with poor foliage formation and fruits, consequently they withered, and since the local farming population in this municipality predominantly cultivates these crops most, a heavy toll is often taken on the annual farmers' income.
\end{abstract}

Keywords: Feeding, Nesting, Weaver-bird, Environmental conditions, Crops

\section{Introduction}

The world population continues to grow, accompanied by rapid urbanization and industrialization. In 2009, more than 50\% of the world's population was living in cities, 1 with the most rapid urban growth in low income regions. In Africa the urban population is likely to triple, and in Asia it will be more than double in a few decades. ${ }^{1}$ Loss of biodiversity is a worldwide phenomenon. ${ }^{2}$ Even though cities only occupy $2.7 \%$ of the world's dry-lands, urbanization leads to several environmental problems including damage to. ${ }^{3,4}$ Birds are globally seen as a flagship group for conservation, ecological and evolutionary reasons, and they occupy a significant place in people's perception of nature. Birds are highly sensitive as well as mobile, and thus eminently suitable to study the impact of anthropogenic disturbance on biodiversity. ${ }^{5,6}$

Birds use a wide variety of plant, animal and artificial materials to construct their nests. ${ }^{7}$ Whilst the nest itself is primarily where eggs are incubated, ${ }^{8}$ it is suggested that they have a range of other
Quick Response Code:

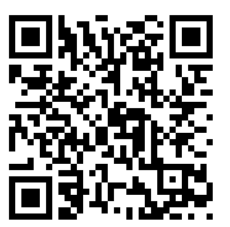

*Corresponding author: Melle Ekane Maurice, Department of Forestry and Wildlife, Faculty of Agriculture and Veterinary Medicine, University of Buea, P. O. Box 63, Buea, Cameroon

Received: 23 October, 2020

Published: 09 November, 2020

Citation: Melle EM, Kato SN, Ewane D, Mbole V, Agborta SO. Weaver-Birds' crop-Raiding Behavior in Buea municipality, Southwest Region, Cameroon. Glob Scient Res Env Sci. 2020;1(1):1-6. DOI: 10.53902/GSRES.2020.01.000501 
roles associated with reproduction, and perhaps even lifetime fitness. ${ }^{9,10}$ Birds select materials during nest construction for a variety of reasons, ${ }^{11}$ including sexual signaling, ${ }^{12,13}$ defense from parasites or pathogens, ${ }^{13}$ camouflage, ${ }^{14,15}$ insulation ${ }^{10,16,17}$ or for their structural role. ${ }^{18-20}$ Whether these materials are deliberately selected for specific roles has yet to be fully investigated, but it is known that variation in a particular type of material reflects its availability within the local environment. ${ }^{21-23}$

Recent studies have tried to determine the factors that affect nest construction both using captive species and by examining nests from the field, particularly in light of the structural properties of the materials. Captive Zebra Finches (Taeniopygia guttata) have been used to demonstrate that the structural properties of artificial materials (string) as well as the experience of the bird influence the materials chosen, with stiffer string appearing to be the more effective building material. ${ }^{18}$ Additionally, captive birds also show an apparent sensitivity to the length of the string. ${ }^{24}$

Wild birds also appear to select materials which play an important mechanical role in construction. Common House Martins (Delichon urbicum) have been shown to enhance the mechanical behavior of mud-based nesting materials, particularly in compression, with the addition of polysaccharide/sugars obtained from abundant plant fruits. ${ }^{25}$ In the nests of Common Blackbirds (Turdus merula) plant-derived materials in the outer nest were found to be thicker, stronger and more rigid compared to the materials present within the structural wall and the cup lining. ${ }^{20} \mathrm{~A}$ similar pattern was observed in the mechanical properties of materials used in the various parts of the nests of Eurasian Bullfnch (Pyrrhula pyrrhula). ${ }^{19}$
The materials used by Bullfinches in the outer nest were thicker and stronger than those used by the much heavier Common Blackbird, which may reflect the absence of an internal mud cup in the Bullfinch nests. ${ }^{19}$ These reports suggest that these birds may have some level of awareness of where and when to place certain materials in order to create a nest structure, although this has yet to be tested experimentally. ${ }^{19}$

Other animals have also been shown to use materials in a non-random manner during the construction of nests and other structures. Orangutans (Pongo spp) build nests in trees that act as sleeping beds. They select stronger, more rigid materials for the outer 'structural' part of the nest compared to the weaker and more flexible materials used to construct the cup lining. ${ }^{26}$ Irrespective of the availability of tree species in one study, Eurasian Beavers (Castor fiber) largely used willow salix branches in building their lodges. ${ }^{27}$ Studies of the structural properties of nest materials are rare, ${ }^{20,19,25,28}$ so little is known about whether birds are generally selective of nest materials based on their biomechanical properties. Weaver-birds are crop-raiders in Cameroon and other countries in sub Saharan Africa. Their prolific reproductive behavior has given them the ability to invade crop-farmland in hug numbers, the reason crop farmers in most areas in Cameroon suffer annual crop-yield shortages. The crop-raiding behavior of weaver-birds also involves nest-building in the farming areas for breeding. This characteristic is the main reason their destruction on crop-farms is heavy and takes an annual income toll on its victims. Hence, this study was focused on the birds' destructive feeding and nesting activities on farm crops in Buea municipality.

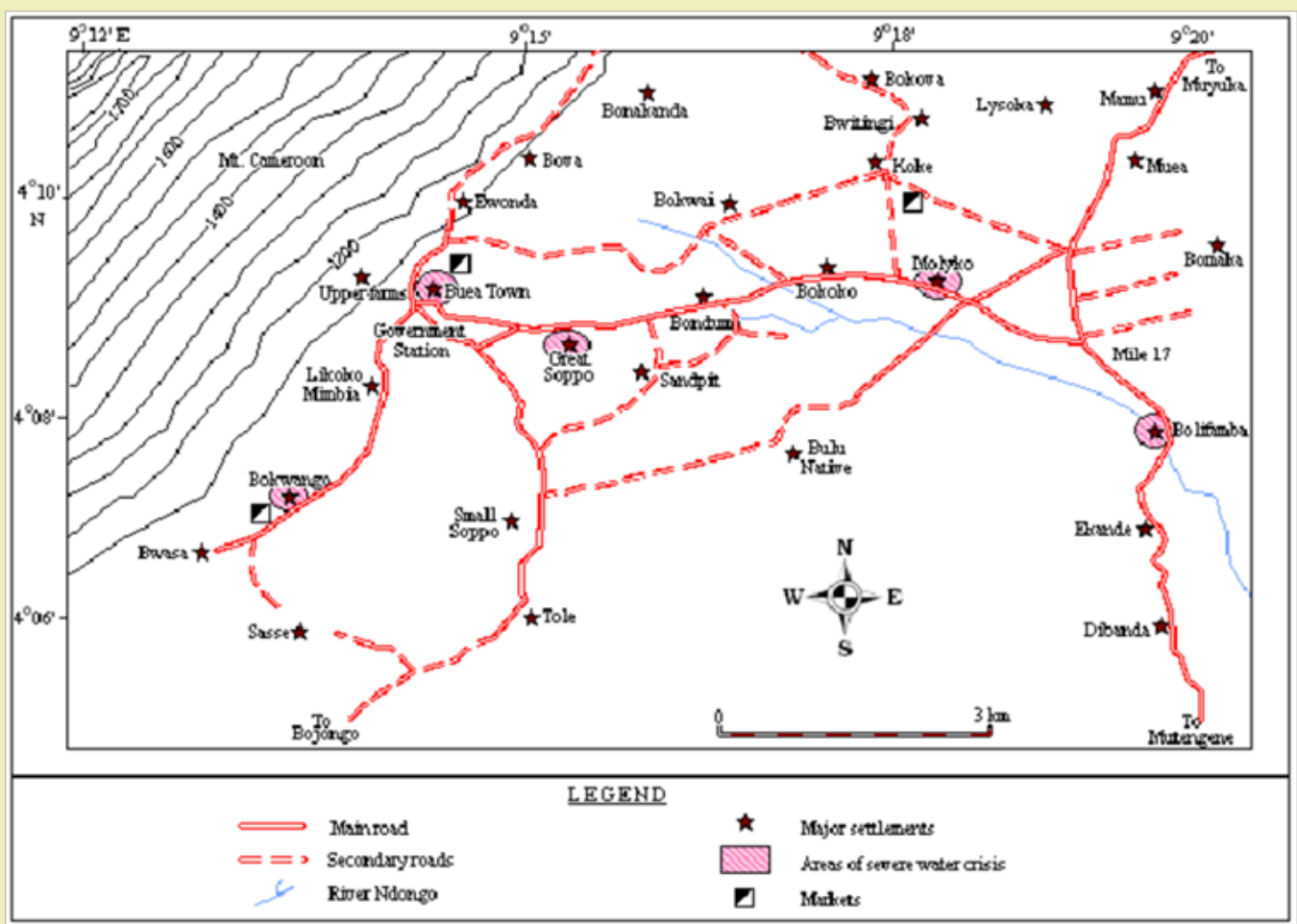

Figure 1: Map of Buea Municipality. 


\section{Materials and Methods}

\section{The description of study area}

Buea municipality is found in the Southwest Region of Cameroon, located between longitude $9^{0} 16^{\prime} \mathrm{E}$ and latitude $4^{0} 9^{\prime} \mathrm{N}$ (Figure1)..$^{29,30}$ The municipality is bounded to the north by tropical forest on the slope of mount Cameroon (4100m above sea level). The population is estimate data bout 300,000 people, of whom twothird live in the city of Buea, while the rest in villages. The settlement pattern forms a closed ring around the foot of the mountain with no permanent settlements on altitudes above $1500 \mathrm{~m}$. The indigenous people in the area are Bakweri, Bomboko, Balondoand Bakolle. ${ }^{31}$ With an equatorial climate, temperature is moderate with a slight seasonal variation (rainy and dry season). ${ }^{29}$ The region is also very diverse in fauna with over 370 species of wildlife recorded. The sub-mountain and mountain habits are part of Cameroon mountain endemic bird area. Sofar, 210 species of birds have been recorded, out of which 8 are threatened and 2 strictly end emicmount Cameroon francolin (Francolinus camerunensis)and mount cameroon speirops (Speirops melanocephalus) ${ }^{31}$. Agriculture is the most important source of livelihood in the area accounting for about $80 \%$ of household income in most villages. Other sources of income include hunting, timber and non-timber forest products (NTFP) exploitation, petty trading, and cattle rearing. ${ }^{30}$

\section{Data collection method}

The research data collection program was done by a research team made up of four persons, the principal investigator and three other student colleagues. The three-month study was carried out in Buea municipality, and the research data was collected between 7:00am-6:00pm each day of the study, and was done 6 days each week, Monday-Saturday. The team visited all the neighborhoods of the city on a daily bases to record observations on bird species, feeding activity, locations, and day-period. A five-minute-spotcount method was used throughout the data collection period. Point counts (where the observer is sedentary at one place), is among the most frequently used techniques for monitoring terrestrial birds. Bird population monitoring programs vary in how they are conducted. The Breeding Bird Survey (BBS), for example, is run in Britain and variants of it are used by 18 other European countries. ${ }^{32}$ Five-minute point-based distance counts are used in France that specify the area of the samplings item and the distance bands used around each point, , $(<25 \mathrm{~m}, 25-100-\mathrm{m}$, and $>100-\mathrm{m}){ }^{32}$

\section{Data analysis}

The research data collected on check-sheets was analyzed by the use of SPSS version 20. And the main statistical model used was chi-square to test the relationships existing between the variables such as bird species, bird feeding and nesting activities, and the neighborhood location. Exploratory analysis was used to further examine the frequency of variables like bird activity, environmental condition, and bird species

\section{Results}

The study recorded a significant association between weaver-birds activity on crop-land, $\mathrm{X}^{2}=11.653 \mathrm{df}=14, \mathrm{P}<0.005$ (Figure
2) and $X^{2}=3.441 \mathrm{df}=4, P<0.05$ (Figure 3 ) respectively. Birds are very important to the natural ecological sustainability, especiallyin the tropics where the rainforest is undergoing intensive depletion due to corruption and mismanagement of public funds. However, the touristic love for bird-watch on some species like weaver-birds has been controversial in wildlife conservation, due to the destructive role played some species of birds in croplands. The weaver-bird feeding activity on maize (Zea mays), avocado (Persea americana), and oil palms (Elaeis guineensis) was significantly recorded in this study. Crop-farming in Buea municipality and other parts of Cameroon has been rendered difficult by the weaver-bird feeding activity, one of the main reasons for the low crop-yield in most cultivation seasons.

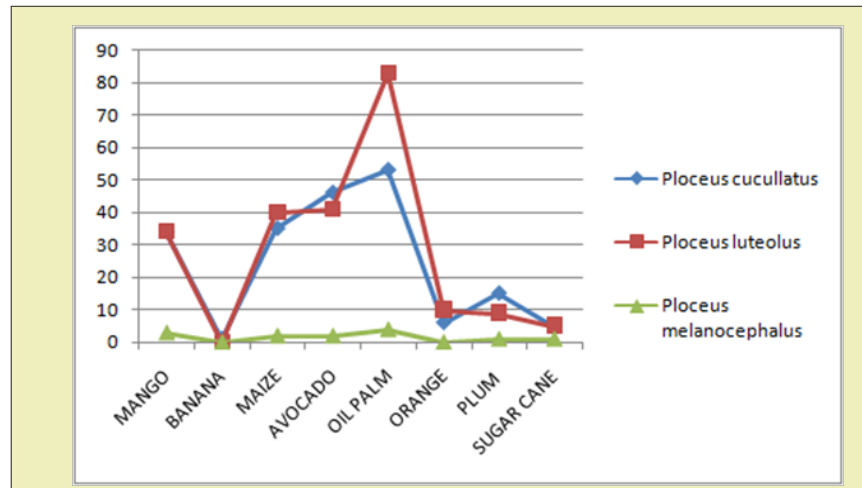

Figure 2: Weaver birds and agriculture.

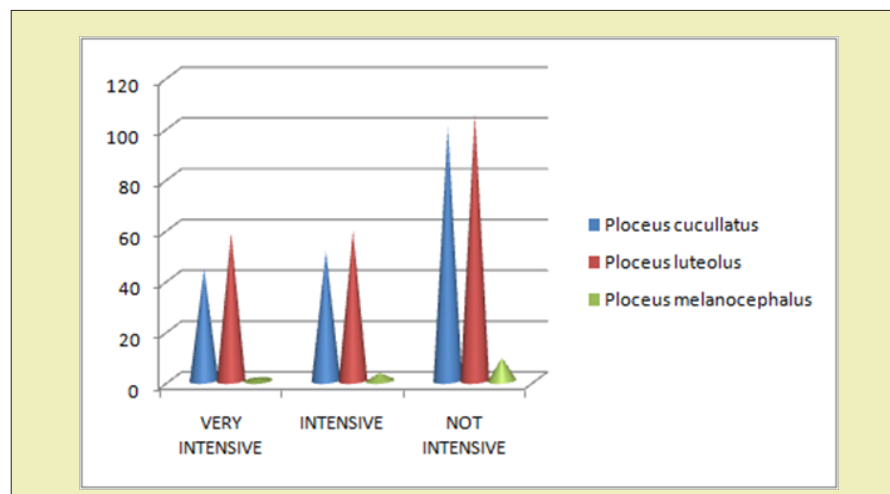

Figure 3: Weaver bird activity on cropland.

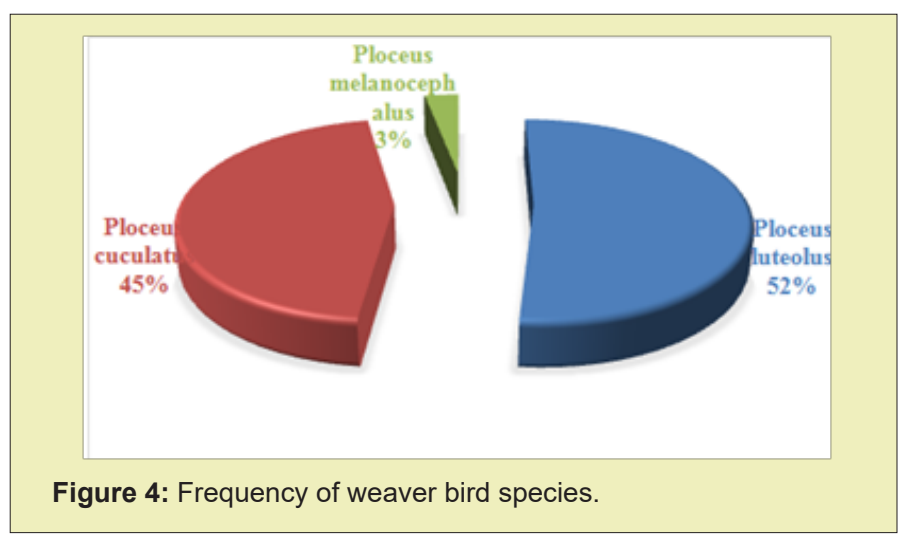

There was weaver-bird activity frequency of $51.63 \%, 45.35 \%$, and $3.02 \%$ for Ploceus luteolus, Ploceus cuculatus, and Ploceus melanocephalus respectively (Figure 4). These bird pests were not only 
frequent in the study area but are among the dominant bird pest in Cameroon and other countries in sub Saharan African region. The bird population is high and a nuisance to the local farming population, affecting their crop-farm yield on both seasonal and annual bases. The major problem farmers in the local and remote communities are facing is fighting the weaver-bird population. Unfortunately, the primitive approach involving the use of stone-throw, drumming, shouting, and hand-clap chasing rather seems to escalate their problems since weaver-birds would fly off to neighboring farmlands during the application of such methods.

Additionally, a week association was recorded between birds' activity and weather, $\mathrm{X}^{2}=3.125 \mathrm{df}=3, \mathrm{P}<0.05$ (Figure 5). The effect of atmospheric conditions has been well known on wildlife behavioral activity changes, influencing both the social and individual activities. The sunny and cloudy weather conditions recorded $53.26 \%$, and $42.09 \%$ respectively, while the windy and rainy weather conditions were significantly low (3.26) (Figure 6). It must also be noted that the turbulent atmospheric condition in mount Fako is characterized with heavy rainfall, wind, and cloud in most parts of the year. Hence, any sunny weather condition, especially in the rainy season is considered as an advantage to wildlife feeding activity. During heavy rains the birds were observed flying into their nests to shelter, waiting for a convenient atmosphere to intensify feeding and their nest-building.

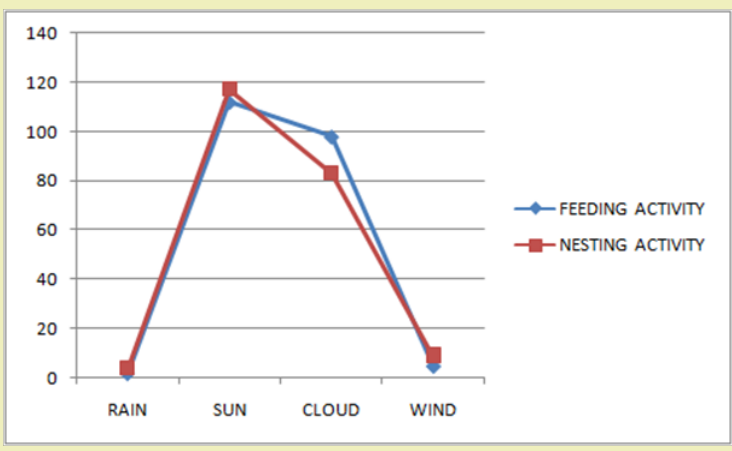

Figure 5: Bird activity and weather.

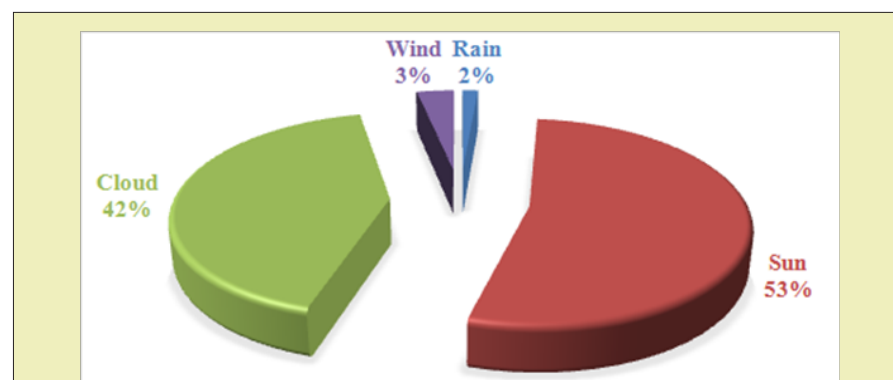

Figure 6: Frequency of activity and weather

Furthermore, human neighborhood showed a significant association on crop species, $\mathrm{X}^{2}=42.253 \mathrm{df}=28, \mathrm{P}<0.05$ (Figure 7). Crop species such as maize, avocado, and oil palms were the most affected in Bokwango, Buea-town, Muea, and Bomaka neighborhoods, while Soppo neighborhood was the least affected. Human neighbor- hood and foliage destruction revealed a significance, $\mathrm{X}^{2}=13.144$ $\mathrm{df}=8, \mathrm{P}<0.05$ (Figure 8). Bomaka neighborhood still recorded the highest foliagedestruction comparatively.

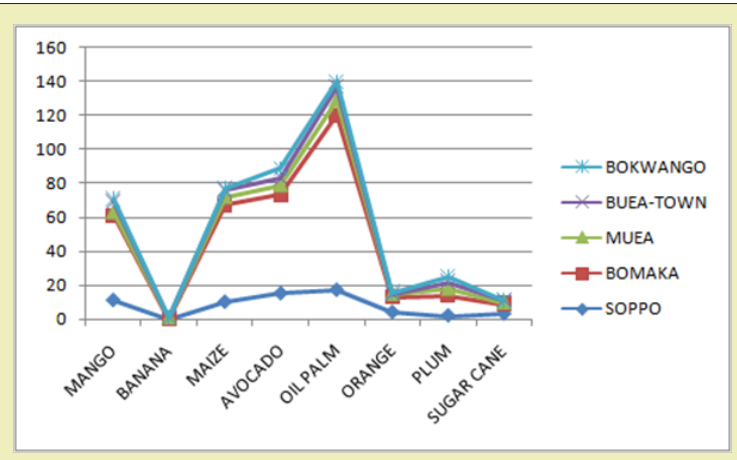

Figure 7: Human neighbourhood and crop species.

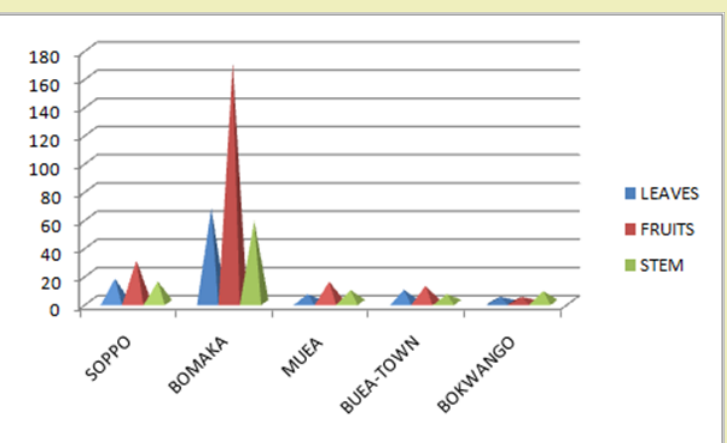

Figure 8: Human neighbourhood and crop-portion destruction

An association was observed between atmospheric conditions and weaver-birds' activity on crops, $\mathrm{X}^{2}=23.249 \mathrm{df}=21, \mathrm{P}<0.05$ (Figure 9). Three weather types, wind, cloud, and sun remarkably favored the activity of birds on maize, avocado, and oil-palm while their activities were low during rainy weather condition. Maize and oil-palms were among the crop species most subjected to destruction by birds. These crops were observed with poor foliage formation and fruits, consequently they withered. Since the local farming population in this municipality is predominantly cultivating these crops most, a heavy toll is often taken on the farmers' annual farm-income. In addition, the most destroyed farms were Elaeis guineensis (32.33\%), Saccharum officinarum (19.77\%), Zea mays (17.44\%), and Mangifera indica (15.58\%) (Figure 10), and the scale of destruction was very prominent on the foliage used by these birds to build their nests.

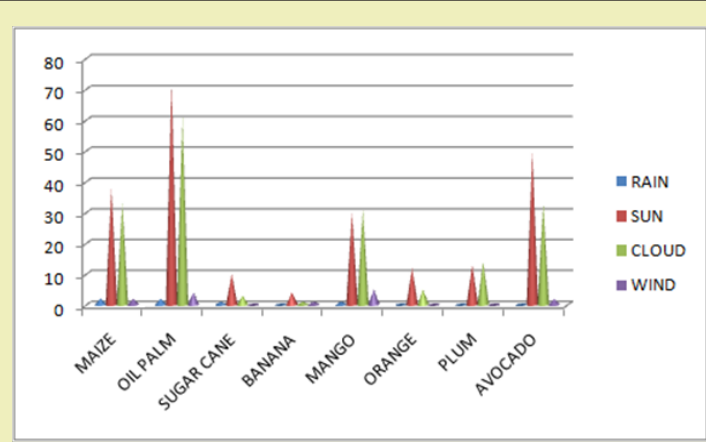

Figure 9: Atmospheric conditions and weaver-birds' activity on crops. 


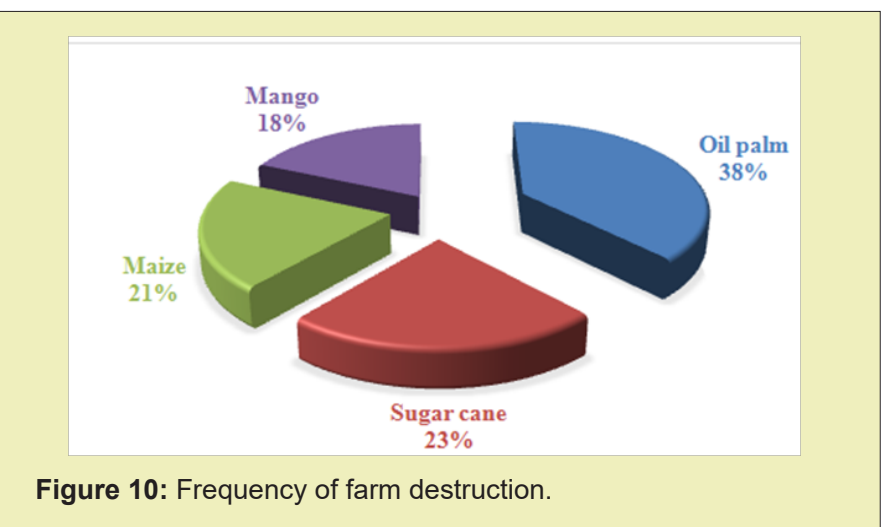

\section{Discussion}

Human wildlife conflict is one of the major threats to conservation, house-hold food security and rural incomes. In Africa, the great dependence of a large proportion of human population for their survival on land, coupled with the presence of many species of large mammals leads to many sources of conflict between people and wildlife. This in turn creates friction between protected area managers and local communities living in the regions that border these protected areas. People have coexisted with wildlife since the early age when they lived a simple hunter-gatherers lifestyle supplementing their diet with fruits and leaves. Man has been and is still a threat to wild plants and animals. There are about 40 species of birds in North, East and Central Africa, which are considered as agricultural pests. ${ }^{33}$ Relatively a few number of all these species do appreciable damage to cultivated crops. Some bird species are extremely destructive, particularly to small grains as in the case of quelea and Bishops. The activity pattern of birds in croplands is influenced by a number of factors such as crop type, non-crop physical structural arrangement and the agricultural practices.34 Shift in cultivation timing also significantly affects the activity pattern of cropland birds, which causes further reduction of the population of farmland birds. ${ }^{35,36}$

Home-garden agro forestry systems (HAS) are complex combinations of multilayered and multispecies vegetation patterns there by, ${ }^{37}$ providing an ideal forest-like habitat to conserve wildlife species by providing sufficient nesting, breeding, food and temporary refuge opportunities all year round. ${ }^{38}$ These habitats are suitable for bird species, such as Common Pigeon (Columba livia), Spotted Dove (Spilopelia chinensis), House Sparrow (Passer domesticus), Scaly-breasted Munia (Lonchura punctulata), Common Myna (Acridotheres tristis), Baya Weaver (Ploceusphilippinus), among others, which are human-tolerant and adjusted to human habitats. These birds have been usually found to build nests and forage for food in and around human settlements..$^{39}$ their breeding season lasts from May to October. ${ }^{40}$ During breeding season, the males moult into a yellow and brown nuptial plumage, while females remain pale brown. ${ }^{40}$ They are granivorous ${ }^{41}$ birds forming enormous communal roosts. ${ }^{42}$

Birds select habitats that fit their requirements for successful reproduction and survival though some generalist species may utilize several habitats. ${ }^{43}$ Differences in requirement among bird spe- cies have caused specificity on habitat requirement. ${ }^{44}$ For example Mountain plover (Charadrius mountainus) feeds primarily on insects (grasshoppers, crickets, beetles, flies, ants); uses ground for nesting and prefer short grass while Mongolian sand plover (Charadrius atrifrons) feeds on invertebrates (molluscs, worms, crustaceans especially crabs and insects), uses tree for nesting and prefer shore of the lakes. Therefore, habitats either terrestrial or aquatic restrict bird species distribution and diversity. ${ }^{45}$ In most habitats, plant communities determine the physical structure of the environment, and therefore, have a considerable influence on the distributions, abundance and diversity of birds and interactions of other animal species. For example, for bird species diversity in forests, 46 evidenced that the physical structure of a plant community, i.e. how the foliage is distributed vertically, may be more important than the actual composition of plant species. ${ }^{47-49}$ found that farmland also has been an important habitat for farmland bird showing that some bird species are habitat specific though some are generalist.

\section{Conclusion}

Green revolution has contributed in enhancing human population growth and distribution around the world. Unfortunately, it's done at the cost of the wild and our surrounding environment that we all depend. The consequence of fighting land space with wildlife is inevitable and it's the main reason wildlife population has suffered a severe decline over many decades. On the other hand local crop-farming areas have been molested by wildlife, especially weaver-birds known to be specialized on cereals, grains, fruits and foliage. Their nest-building activity and feeding on crop-farms have been a major problem faced by local crop-farmers in Cameroon and most parts of Africa. Reduction of the bird population on crop-land has given sleepless nights to both wildlife and agronomic researchers over years due to its prolific reproduction nature and its ability to cover long flight distances for crop-raiding. Though the bird population is not very high in southern Cameroon as compared to north, the damage on crop-farms is significantly embarrassing to the annual farm income of most farmers in places like Buea.

\section{Acknowledgments}

None.

\section{Funding}

None.

\section{Conflicts of Interest}

Author declares that there is no conflict of interest.

\section{References}

1. UN. Global cooperation needed to protect pathways of migratory species, Head of UN-backed convention urges greater effort to combat illegal rhino trade. 2011.

2. Butchart SHM, Walpole M, Collen B, et al. Global biodiversity: indicators of recent declines. Science. 2010;328(5982):1164-1168.

3. Kareiva P, Watts S, Mc Donald R, et al. Domesticated nature: shaping landscapes sand ecosystems for human welfare. Science. 2007;316(5833):1866-1869.

4. Grimm NB, Faeth SH, Golubiewski NE, et al. Global change and the ecology of cities. Science. 2008;319(5864):756-760. 
5. Chazdon RL, Peres CA, Dent D, et al. The potential for species conservation in tropical secondary forests. Conservation Biology. 2009;23(6):1406-1417.

6. Gibson L, Lee TM, Koh L P, et al. Primary forests are irreplaceable for sustaining tropical biodiversity. Nature. 2011;478:378-383.

7. Hansell MH. Bird nests and construction behaviour. Cambridge University Press. 2000.

8. Deeming DC, Mainwaring MC. Functional properties of nests. In: Deeming $D C$, Reynolds SJ, editors. Nest, eggs, and incubation: new ideas about avian reproduction. Oxford: Oxford University Press. 2015. p. 29-49.

9. Moreno J. Avian nests and nest-building as signals. Avian Biol Res. 2012;5(4):238-251.

10. Mainwaring MC, Hartley IR, Lambrechts MM, et al. The design and function of birds' nests. Ecol Evol. 2014a;4(20):3909-3928.

11. Mainwaring MC, Deeming DC, Jones CI, et al. Adaptive latitudinal variation in Common Blackbirds (Turdus merula nest) characteristics. Ecol Evo. 2015;4(6):841-851.

12. Dubiec A, Góźdź I, Mazgajski TD. Green plant material in avian nests. Avian Biol Res. 2013;6(2):133-146.

13. Tomás G, Merino S, Martinez-de la Puente J, et al. Nest size and aromatic plants in the nest as sexually selected female traits in Blue Tits. Behav Ecol. 2013;24(4):926-934.

14. Kull RC. Color selection of nesting material by Killdeer. The Auk. 1997;94(3):602-604.

15. Bailey IE, Muth F, Morgan KV, et al. Birds build camoufaged nests. Bio one 2015;132(1):11-15.

16. Hilton GM, Hansell MH, Ruxton GD, et al. Using artificial nests to test importance of nesting material and nest shelter for incubation energetics. The Auk. 2004;121(3):777-787.

17. Dhandhukia SN, Patel PK. Selection of nesting sites and nesting material in Common Myna (Acridotherestristis) in an urban area. Int J Pharm Life Sci. 2012;3(8):1897-1904.

18. Bailey IE, Morgan KV, Bertin M, et al. Physical cognition: birds learn the structural efcacy of nest material. Proc $R$ SocLond B. 2014; 281:e20133225.

19. Biddle LE, Goodman AM, Deeming DC. Construction patterns of birds' nests provide insight into nest-building behaviours. Peer J. 2017;5:e3010.

20. Biddle LE, Deeming DC, Goodman AM. Morphology and biomechanics of the nest of the Common Black bird. Turdus merula. Bird Study. 2015;62(1):87-95

21. Álvarez E, Belda EJ, Verdejo J, et al. Variation in Great Tit nest mass and composition and its breeding consequences: a comparative study in four Mediterranean habitats. Avian Biol Res. 2013;6(1):39-46.

22. Cantarero A, López Arrabé J, Moreno J. Selection of nest site and nesting material in the Eurasian Nuthatch Sitta europaea. Ardea. 2015;103(1):91-94

23. Briggs KB, Deeming DC. Use of materials in nest construction by Pied Flycatchers (Ficedula hypoleuca refects)localised habitat and geographical location. Bird Study. 2016; 63(4):516-524.

24. Muth F, Healy SD. Zebra Finches select nest material appropriate for a building task. Anim Behav. 2014;90:237-244.

25. Silva B, Correia J, Nunes F. Bird nest construction-lessons for building with earth. WSEAS Trans Environ Dev. 2010;6(2):82-92.

26. Van CasterenA, Sellers WI, Thorpe SS, et al. Nest-building orang-utans demonstrate engineering know-how to produce safe, comfortable beds. Proc Natl Acad Sci. 2012;109(18):6873-6877.

27. Fustec J, Cormier JP. Utilisation of woody plants for lodge construction by European beaver (Castor fber) in the Loire valley, France. Mammalia. 2007;71(1-2):11-15.

28. Bailey IE, Morgan KV, Oschadleus HD, et al. Nest-building males' trade of material collection costs with territory value. Emu-Austral Ornithology. 2016;116(1):1-8
29. Tanjong E. Socio economic survey of the villages of Mount Cameroon National Park (MCNP). Program for Sustainable Management of Natural Resources Cameroon-South-West Region, Buea, Cameroon. 2014;117:529-38

30. Fitton JD, Kilburn CRJ, Thirwall MF. 1982 eruption of Mt. Cameroon, West Africa. Nature. 1983;306: 327-332.

31. Ekane NB. The Socio Economic Impact of Pronus Africana Management in the Mount Cameroon Region. Case study of the Bukwango Community. Presented as partial fulfilment of the degree of M Sc. From the department of Urban Planning and Environment, Royal Institute of Technology Stock holm. 2000.

32. Spurr EB. Monitoring bird populations in New Zealand: a work shop to assess the feasibility of a national bird population monitoring scheme. In: Bezar C, editor. Land care Research Science Series No 28. Lincoln; 2005.

33. Schmutterer H. Pests of Crops in Northeast and Central Africa with Particular Reference to the Sudan. Gustav Fischer Verlag, Stuttgart and Portland. 1969:136-138.

34. Rodenhouse NL, Best LB, O'Conner. Effect of agricultural Practices and farmland structure. In: Marrin TE, Finch DM, editors. Ecology and management of neotropical birds: a synthesis and Review of critical issue. New York: Oxford University Press; 2007.p 269-293.

35. Best LB. Conservation tillage: ecological traps for nesting birds? Wildlife Society Bulletin. 1986;14:308-317.

36. Jobin B, Des Granges JL, Boutin C. Population trends in selected species of farmland birds in relation to recent developments in agriculture in the St. Lawrence Valley. Agriculture, Ecosystems \& Environment. 1996;57(2-3):103-116.

37. Kehlenbeck K, Maass BL. Crop diversity and classification of homegardens in Central Sulawesi, Indonesia. Agroforestry Systems. 2004;63: 53-62.

38. Griffith DM. Agroforestry: A refuge for tropical biodiversity after fire. Conservation Biology. 2000;14(1):325-326.

39. Soni VC, Sharma PL, Dave SM. Nesting ecology of some terrestrial birds in Rajkot City (Gujrat). Current Bio Science. 2004;97-104.

40. Ali S, Ripley SD. Compact Handbook of the Birds of India and Pakistan Together with those of Bangladesh, Nepal, Bhutan and Sri Lanka- $2^{\text {nd }}$ Edition. India: Oxford University Press, Delhi; 1987.

41. Avery ML. Food preferences and damage levels of some avian rice field pest in Malaysia. Bird Control Seminars Proceedings. 1979;161-166.

42. Gadgil M, Ali S. Communal roosting habits of Indian Birds. Journal of Bombay Natural History Society. 1975;72(3):716-727.

43. Rodríguez Estrella R. Land use changes affect distributional patterns of desert birds in the Baja California peninsula. Mexico: Bird distribution and human activity in Baja California. Divers Distrib. 2007;13(6):877-889.

44. Bucklay HL, Freckleton RP. Understanding the role of Species dynamics in abundant occupancy relationship. J Ecol. 2020;98(3):645-658.

45. Maclean GL. The pygmy falcon (Polihierax semitorquatus). Koedoe.1970;13:1-20.

46. Tewes E, Terrasse M, Sánchez JJ. Action plan for the recovery and conservation of vultures on the Balkan Peninsula: activities and projects during 2002 and 2003. 2004;1-36.

47. Ranganathan J, Chan KMA, Daily GC. Satellite detection of bird communities in tropical countryside. Ecological Applications. 2007;17(5):1499-1510.

48. Deeming DC. How does the bird-nest incubation unit work?. Avian Biol Res. 2016; 9(2):103-113.

49. Rosenstock SS, Anderson DR, Giesen KM. Landbird counting techniques current practices and an alternative. The Auk. 2002;119(1):46-48. 